\title{
Morphology and dynamics of the Malekhu Khola, Dhading district, central Nepal
}

\author{
*Niraj Bal Tamang and Naresh Kazi Tamrakar \\ Central Department of Gology, Tribhuvan University, Kathmandu, Nepal \\ (*Email: nirajbaltamang89@gmail.com)
}

\begin{abstract}
Rivers have always been an indispensable part of the human civilization. They play a vital role in daily life purposes to big engineering constructions such as dams, reservoirs or hydropower projects. It is mandatory to understand the morphology and dynamics of the river before initiating any projects for easier planning and to prevent possible damage to structures. The Malekhu Khola area is one of the potential areas for urbanization and has already been undergoing development of settlement and other infrastructures. This paper describes the morphology and dynamics of the Malekhu Khola to classify and characterize the river's behavior and competency. The Malekhu Khola is a sixth-order river having its total length of $24.83 \mathrm{~km}$, watershed area of 101.28 $\mathrm{km}^{2}$ and the average gradient of $0.041 \mathrm{~m} / \mathrm{m}$. Various morphological parameters were measured with the aid of topographic maps, aerial photographs and Geographic Information System (GIS). The hydraulic parameters, channel sediment and slopes were measured at 10 different transects sites through field surveys. The river was classified using the Rosgen's Level II criteria. The river reaches have been classified as A4-, B4- and C4-type streams. A4- and B4-type streams are moderate-gradient gravelly and low sinuosity rivers whereas C4-type streams are low-gradient gravelly meandering river. The Malekhu Khola gradually changes from A4- to B4-type streams up to $12 \mathrm{~km}$ downstream, and then to C4-type stream further downstream, but B4-type streams reappear within the distance of $15 \mathrm{~km}$ to $19 \mathrm{~km}$ from the origin. This study presents temporal changes in river channel, and flow competence and aggrading/degrading potential evaluation of the Malekhu Khola.
\end{abstract}

Keywords: Fluvial morphology, river classification, hydraulic parameters, temporal changes, Malekhu Khola.

Paper Received: 22 April 2015

Paper Accepted: 29 December 2015

\section{INTRODUCTION}

Rivers are one of the dynamic components of the nature. They play the role of destructive agent through erosion and scouring while that of constructive agent through deposition. Rivers are significant geomorphological agents that exhibit diversity of pattern and behaviour (Selby 1983). The characteristics of the river are required to understand before initiating any activities near it. In regions of active tectonics, the mass movements and valley floor aggradations are prominent (Marutani et al. 2001). The Malekhu Khola is a $24.83 \mathrm{~km}$ long river flowing S-N with a watershed area of $101.28 \mathrm{~km}^{2}$ and ranging in altitude from $330 \mathrm{~m}$ up to $2,320 \mathrm{~m}$ amsl (above mean sea level). The Malekhu Khola area is one of the potential areas for urbanization and has already been undergoing development of settlement and other infrastructure (Fig. 1).

Understanding of river dynamism and its related processes, and river stability condition are very important for watershed management, wetland management, flooding mitigation, reservoir sedimentation management and sustainable development of infrastructures (Tamrakar and Shrestha 2012). Tamrakar and Shrestha (2008) suggested that rivers originating from the Lesser Himalaya with unstable slope are even more capable to flush out sediment compared to the rivers of the Siwaliks. Thus, depending on the terrains, dynamism of rivers may alter as reflected by some changes

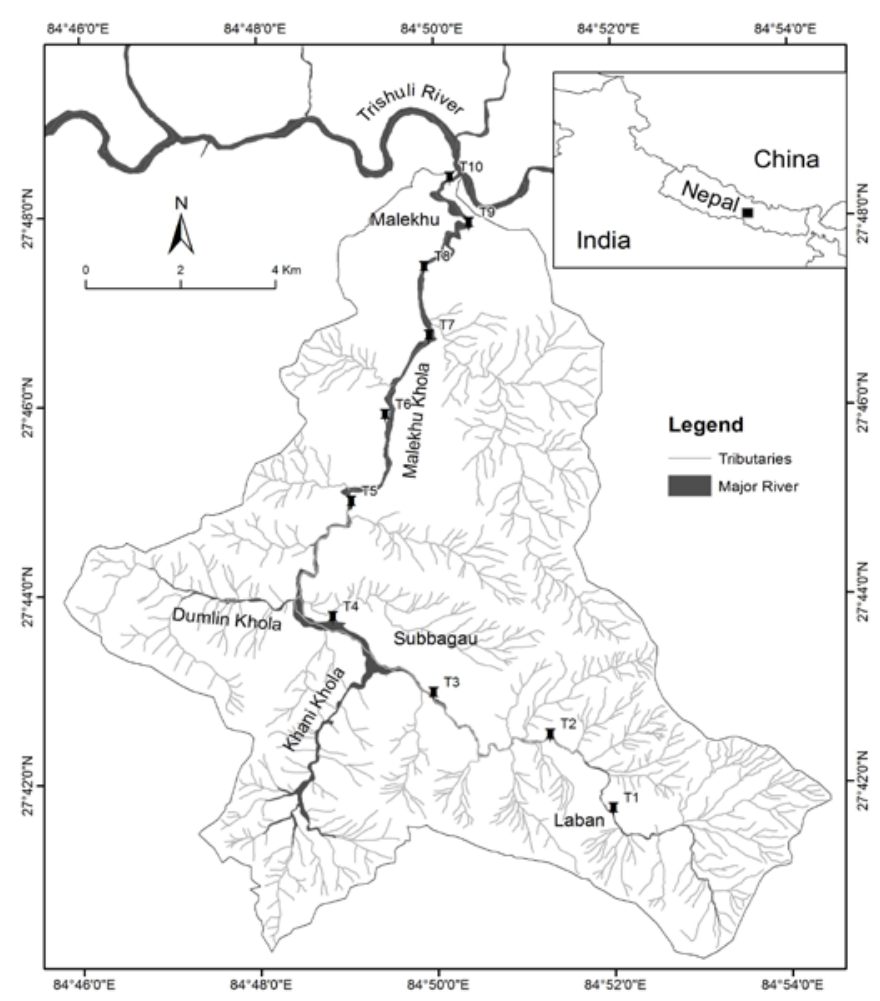

Fig. 1: Location map of the study area showing the Malekhu Khola watershed and transect sites. 
of various morphological attributes such as slopes, sinuosity, entrenchment ratio, width/depth ratio, etc. This paper assesses morphological attributes and presents stability status of the Malekhu Khola.

\section{GEOLOGICAL SETTINGS}

Geology of the study area (Fig. 2) is based on the work of UNDP (1981), Stocklin (1980) and the present survey along the Malekhu Khola Corridor. The Malekhu Khola Watershed (MKW) lies on the rocks of the Lesser Himalaya, comprising the autochthonous Nawakot Complex and the allochthonous Kathmandu Complex. There is a massive granite intrusion (Agra Granite) in the Tistung Formation of the Phulchauki Group (Table 1). The Nawakot Complex consists almost exclusively of low-grade metasedimentary rocks. It has been subdivided into the Lower and Upper Nawakot Groups. The
Kathmandu Complex has been divided into the Precambrian Bhimphedi Group (Nadgir et al. 1973), consisting of relatively high-grade metasedimentary rocks, and the Phulchauki Group of unmetamorphosed or weakly metamorphosed rocks containing fossils of Early-Middle Palaeozoic age. The Mahabharat Thrust passes through the MKW separating the Nawakot Complex from the Kathmandu Complex. The dominant structural feature is the large, WNW-ESE trending Mahabharat Synclinorium, a doubly plunging megafold with steep flanks, a well-developed western closure and a narrow, elongated eastern wing. The core of the Mahabharat Synclinorium extends in WNW-ESE direction at the southern part of the MKW. Left part of the watershed lies in the western closure of the eastward plunging Mahabharat Synclinorium, from where the rock formations of the northern limb extend NE-SW and southern limb extends NW-SE.

Table 1 : Geological information of the Malekhu Khola watershed (based on Stocklin 1980).

\begin{tabular}{|c|c|c|c|c|c|}
\hline Terrain & Complex & Group & Formation & Lithology & Age \\
\hline \multirow{11}{*}{ 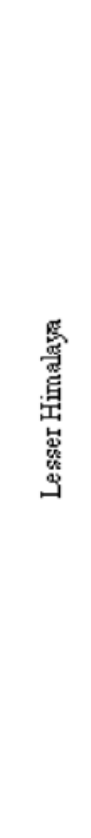 } & \multirow{8}{*}{ 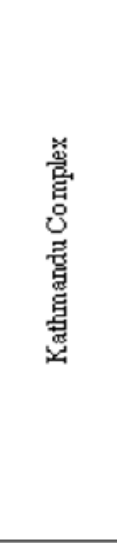 } & 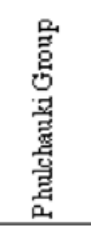 & Tistung Formation & me tasandst one, phyllite, metasiltstone, shale. & Early Cambrian \\
\hline & & \multicolumn{4}{|c|}{ Unconformity? } \\
\hline & & \multirow{6}{*}{ 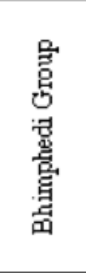 } & Markhu Formation & calcareo us schist, limest one, quartzite. & Precambrian \\
\hline & & & Kulikhani Formation & biotite schist, quartzose schist, quartzite. & Precambrian \\
\hline & & & Chisapani Quartzite & white quartz ite. & Precambrian \\
\hline & & & Kalitar Formation & biotite schist, quartzite. & Precambrian \\
\hline & & & Bhainse dobhan Marble & marble. & Precambrian \\
\hline & & & Raduwa Formation & gametiferous schist. & Precambrian \\
\hline & \multicolumn{5}{|c|}{ Mahabharat Thrust } \\
\hline & \multirow{2}{*}{ 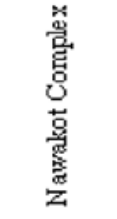 } & \multirow{2}{*}{ 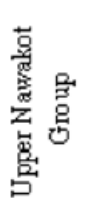 } & Robang Formation & phyllite, sericite quartzite, amphibolite. & Post Early Palaeoz oic \\
\hline & & & Malekhu Limestone & limestone, dolorite. & Post Early Palaeoz oic \\
\hline
\end{tabular}




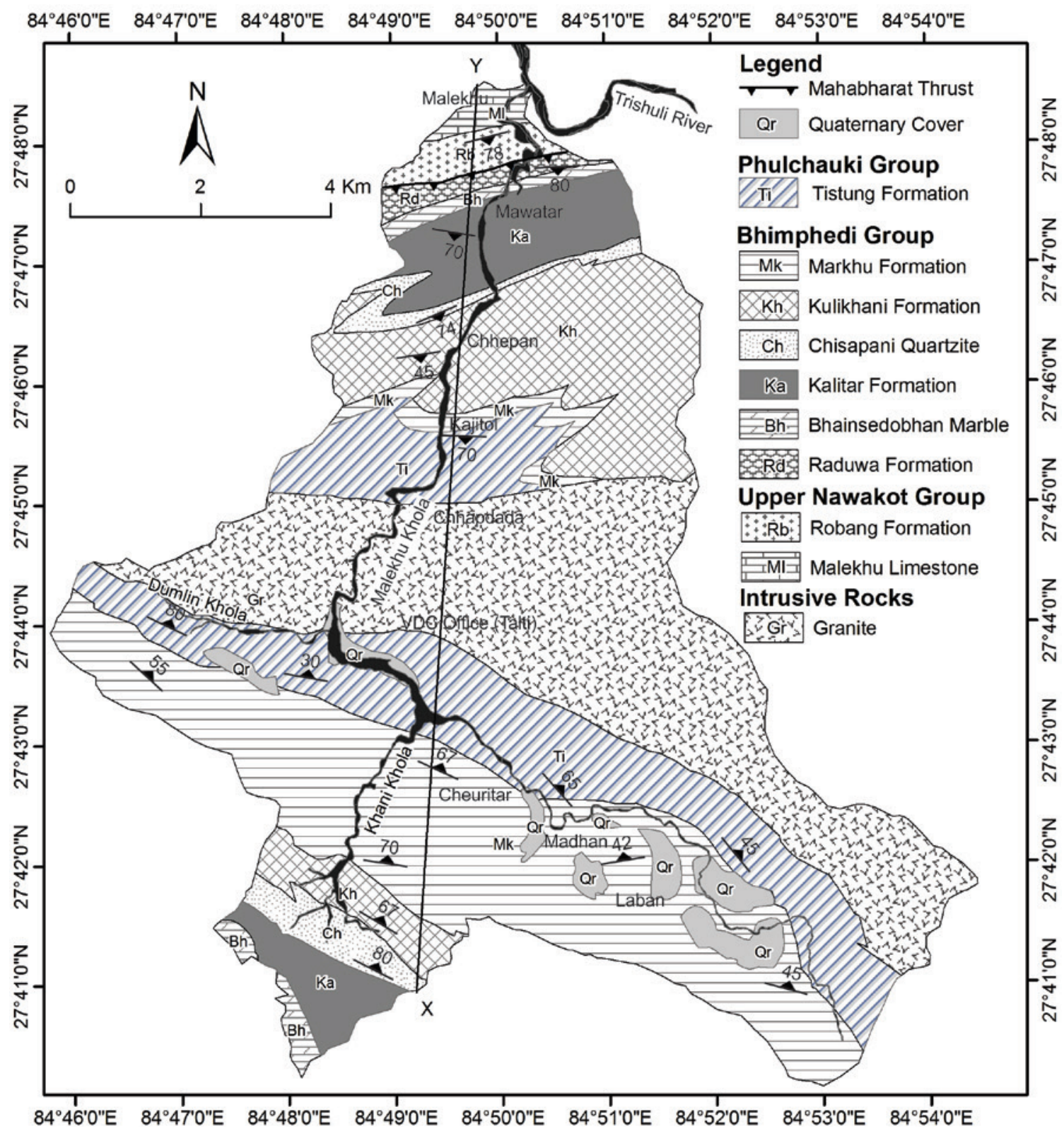

Fig. 2. Geological map of the Malekhu Khola watershed (after UNDP 1981).

\section{METHODOLOGY}

River morphology were assessed along the Malekhu Khola Corridor (MKC) from upstream to the downstream, starting from Laban to the Malekhu Bridge. Altogether, ten transects were taken at different sections of the river along with the Wolman Pebble Count and hydraulic data measurement at each transect to get the representative data of the whole Malekhu Khola. In the laboratory, the aerial photographs, topographic maps, Google Earth Images and digital topographic layers were analyzed to get (a) regional parameters, (b) planform parameters and (c) temporal changes in river channel.

\section{WATERSHED-SCALE PARAMETERS OF THE MALEKHU KHOLA}

Stream order, length of each stream order of the main stem, subwatershed area for each stream order of the main stem, longitudinal profile and relative relief were measured as the watershed parameters.

\section{Stream order, length and subwatershed area}

Stream order is defined as 'a measure of the position of a stream in the hierarchy of tributaries' (Leopold et al. 1964), was determined for MKW after Strahler (1957, 1964) using GIS. After determining the stream order (Fig. 3), the length of 
each order of the main stem was measured. The subwatershed consists of a single tributary or a network of tributaries contributing to the main stem. The subwatershed area of each stream-order section of MKW (Fig. 3) was measured using GIS.

The Malekhu Khola is a $24.83 \mathrm{~km}$ long sixth-order stream and has the watershed area of $101.28 \mathrm{~km}^{2}$. The sixth order of the Malekhu Khola is the longest section of length of $11.49 \mathrm{~km}$ and also covers largest watershed area of $70.28 \mathrm{~km}^{2}$.

Table 2 : Watershed-scale parameters of the MKW.

\begin{tabular}{|l|c|c|c|c|c|c|c|}
\hline Stream Order & $\mathbf{1}$ & $\mathbf{2}$ & $\mathbf{3}$ & $\mathbf{4}$ & $\mathbf{5}$ & $\mathbf{6}$ & Total \\
\hline Length $(\mathrm{km})$ & 0.35 & 1.16 & 2.59 & 6.32 & 2.92 & 11.49 & 24.83 \\
\hline $\begin{array}{l}\text { Subwatershed } \\
\text { area }\left(\mathrm{km}^{2}\right)\end{array}$ & 0.03 & 0.42 & 2.35 & 21.3 & 6.9 & 70.28 & 101.28 \\
\hline
\end{tabular}

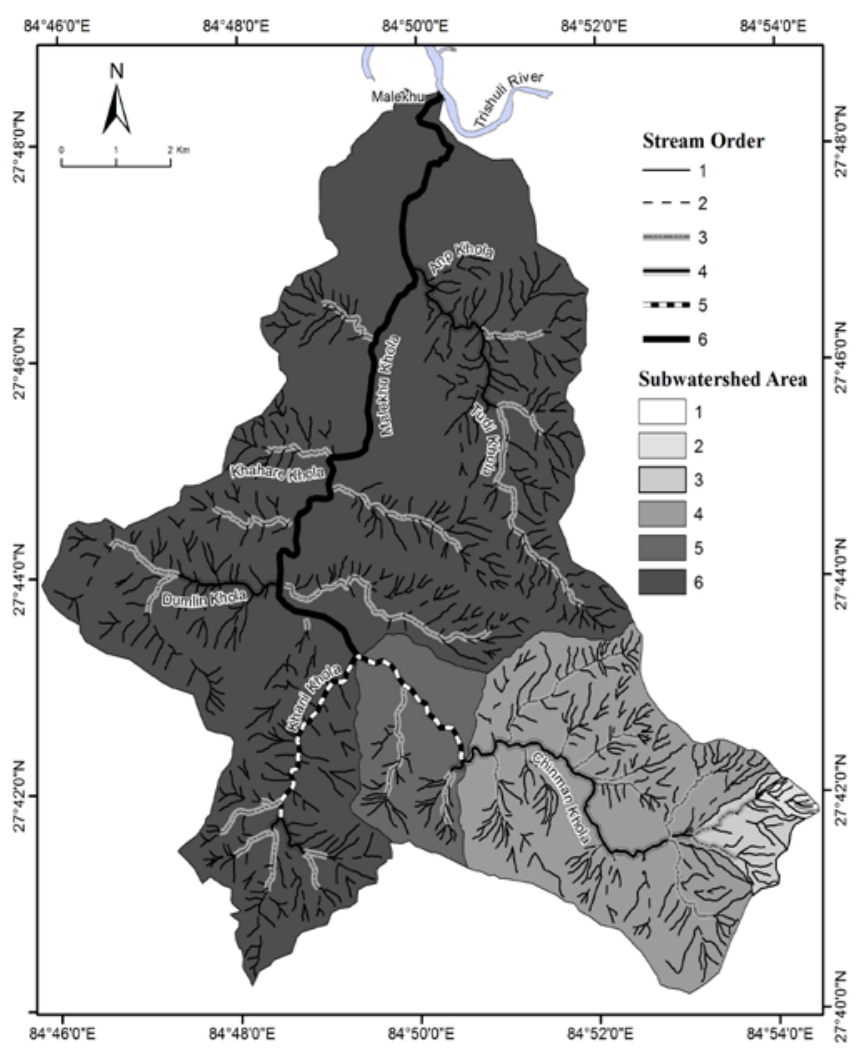

Fig. 3: Stream order of major tributaries and orderwise subwatershed area for the main stem of the Malekhu Khola.

\section{Longitudinal profile}

Longitudinal profile (Fig. 4) helps to understand the change in slope with respect to distance throughout the whole stream. Knick points are present in various portions at $1.2 \mathrm{~km}$, $16.6 \mathrm{~km}$ and $20 \mathrm{~km}$ from the origin of the profile indicating the eroding tendency of the stream.

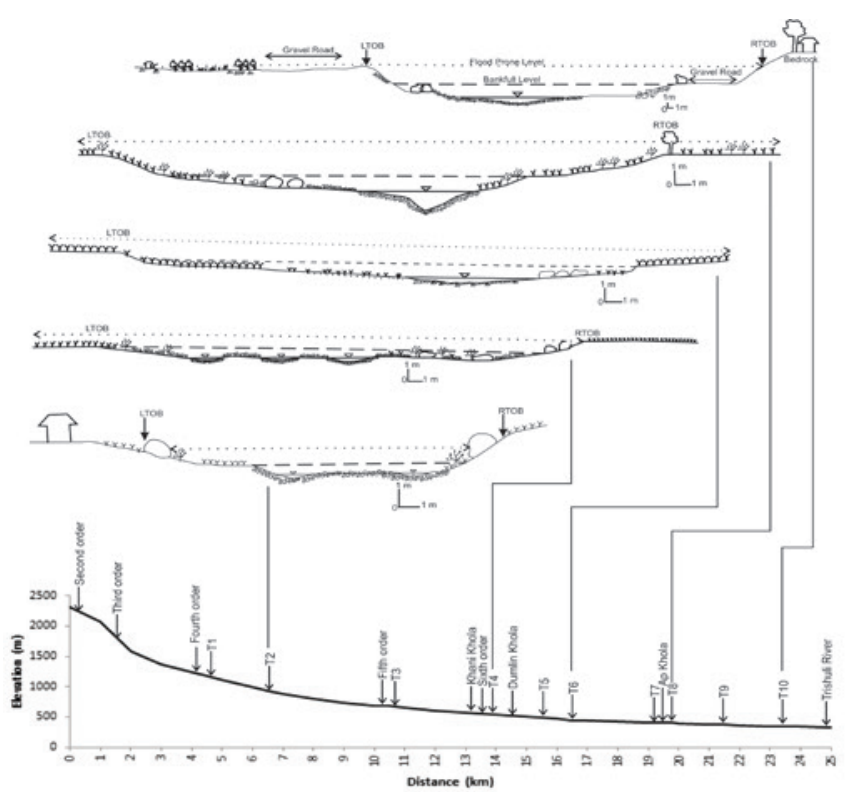

Fig. 4 : Longitudinal section of the Malekhu Khola along with five figures out of ten cross-sections. The vertical scale is exaggerated two times the horizontal scale.

\section{Relative relief}

Relative relief is defined as the difference in height between the highest point and the lowest points. The relative relief map (Fig. 5) is prepared using the Digital Elevation Model (DEM). The watershed area has relief ranging from 200-253 m. Most of the upstream area towards the south and the right bank in downstream portions have high relieves. Most portions of the left bank of the Malekhu Khola, from Dumlin Khola up to the Malekhu Bridge have low relieves.

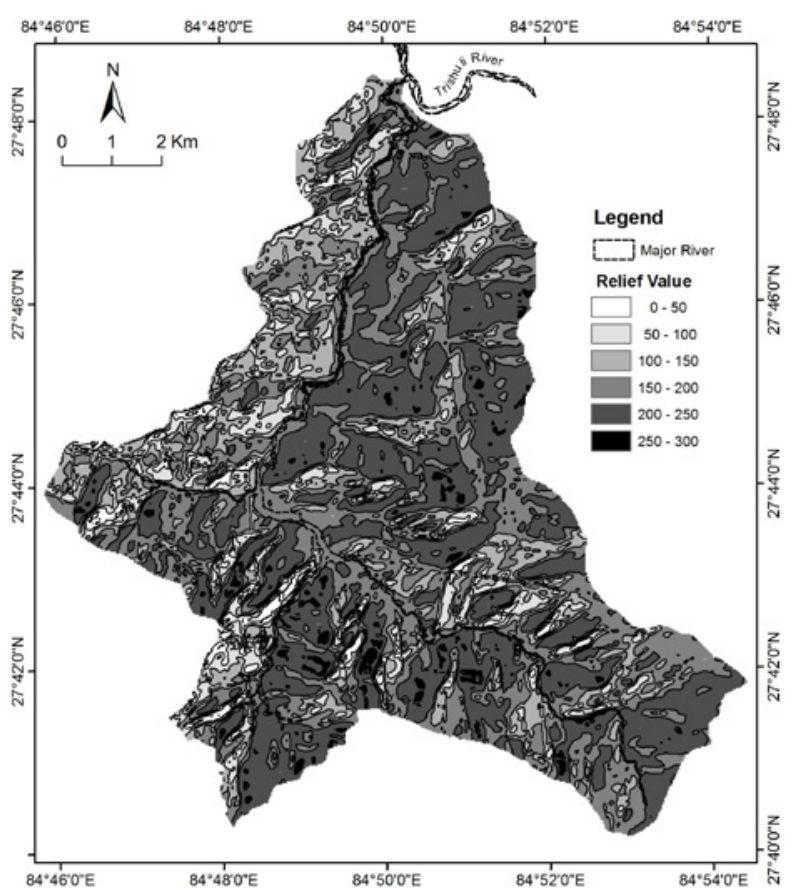

Fig. 5: Relief map of the Malekhu Khola watershed. 


\section{PLANFORM PARAMETERS OF THE MALEKHU KHOLA}

Sinuosity, meander belt width, meander wavelength and radius of curvature

The planform parameters were measured using the topographic maps and the aerial photographs. Sinuosity (K) is the ratio of stream channel length to down-valley distance. Meander wavelength $\left(\mathrm{L}_{\mathrm{m}}\right)$ of the river is the distance between two successive crests or two successive trough of the curved channel. Meander belt width $\left(\mathrm{W}_{\mathrm{blt}}\right)$ is a straight line between the crest of the bend to the crest of the next bend lying downstream, or is the distance between lines defining the confinement of the lateral boundaries of the channel. Radius of curvature $\left(\mathrm{R}_{\mathrm{c}}\right)$ is the radius of a circle drawn through the apex of the bend and the two crossover midpoint of river, and is defined as the curved surface formed by the meandering stream channels (Tamrakar and Bajracharya 2012). From Table 3, it was observed that the sinuosity of the Malekhu Khola ranges from 1.06 to 1.51 , the radius of curvature ranges from 0.069 to $0.513 \mathrm{~km}$, the meander wavelength ranges from $0.231-0.850$ $\mathrm{km}$ and the meander belt width ranges from $0.15-0.725 \mathrm{~km}$.

Table 3: Planform parameters of the Malekhu Khola.

\begin{tabular}{|l|c|c|c|c|c|c|c|c|c|c|}
\hline Taransect & $\mathbf{1}$ & $\mathbf{2}$ & $\mathbf{3}$ & $\mathbf{4}$ & $\mathbf{5}$ & $\mathbf{6}$ & $\mathbf{7}$ & $\mathbf{8}$ & $\mathbf{9}$ & $\mathbf{1 0}$ \\
\hline Sinuosity & 1.08 & 1,15 & 1,27 & 1.06 & 1.51 & 1.22 & 1.08 & 1.07 & 1.06 & 1.44 \\
\hline Radius of curvature $(\mathrm{km})$ & 0.175 & 0.269 & 0.156 & 0.419 & 0.172 & 0.306 & 0.513 & 0.363 & 0.069 & 0.158 \\
\hline Meandar wavelength $(\mathrm{km})$ & 0.675 & 0.444 & 0.338 & 0.756 & 0.419 & 0.85 & 0.844 & 0.619 & 0.231 & 0.513 \\
\hline Meander belt width $(\mathrm{km})$ & 0.275 & 0.15 & 0.15 & 0.45 & 0.525 & 0.225 & 0.5 & 0.325 & 0.725 & 0.425 \\
\hline
\end{tabular}

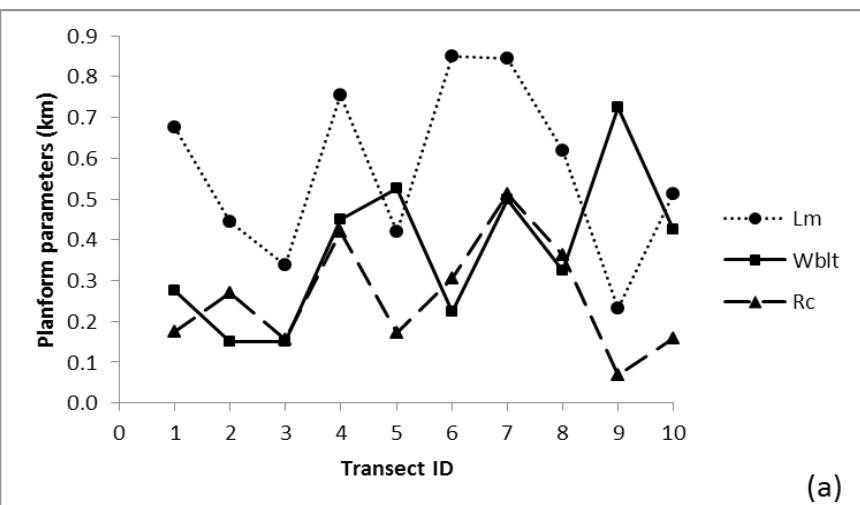

Fig. 6: Downstream variation of the planiform parameters (a) Fluctuating trends of meandering wavelength, meander belt width and radius of curvature (b) Fluctuating trend of sinuosity.

The plot of planform parameters versus the transect (Fig. 7) shows the fluctuating trends of the meandering wavelength, meander belt width and the radius of curvature. The radius of curvature shows somewhat directly proportional relation to the meander wavelength except at Transect 1 . The plot of sinuosity versus the transect shows fluctuating trend and on the basis of correlation of the obtained value with standard values by Leopold and Wolman (1957), the Malekhu Khola is assigned as the sinuous river.

\section{HYDRAULIC PARAMETERS}

Due to the lack of the gauge station, velocity (V) and discharge (Q) of the Malekhu Khola were estimated through the Manning's equation and continuity equation (Chow 1959), respectively as:

$$
\begin{aligned}
& \mathrm{V}=\left(\mathrm{R}^{2 / 3} \cdot \mathrm{S}^{1 / 2}\right) / \mathrm{n} \\
& \mathrm{Q}=\mathrm{V} \cdot \mathrm{A}
\end{aligned}
$$

where, $\mathrm{R}$ is hydraulic radius $(\mathrm{m}), \mathrm{S}$ is average channel slope $(\mathrm{m} / \mathrm{m}), \mathrm{n}$ is Manning's roughness coefficient, $\mathrm{A}$ is the cross-sectional area $\left(\mathrm{m}^{2}\right)$. $\mathrm{R}$ is the ratio of $\mathrm{A}$ to sum of width and twice the bankfull depth.

Entrenchment Ratio (ER) was calculated using following expression (Rosgen 1993):

$$
\mathrm{ER}=\mathrm{W}_{\mathrm{fpa}} / \mathrm{W}_{\mathrm{bkf}}
$$

where, $\mathrm{W}_{\mathrm{fpa}}$ is flood prone width $(\mathrm{m})$ and $\mathrm{W}_{\mathrm{bkf}}$ is bankfull width (m). 

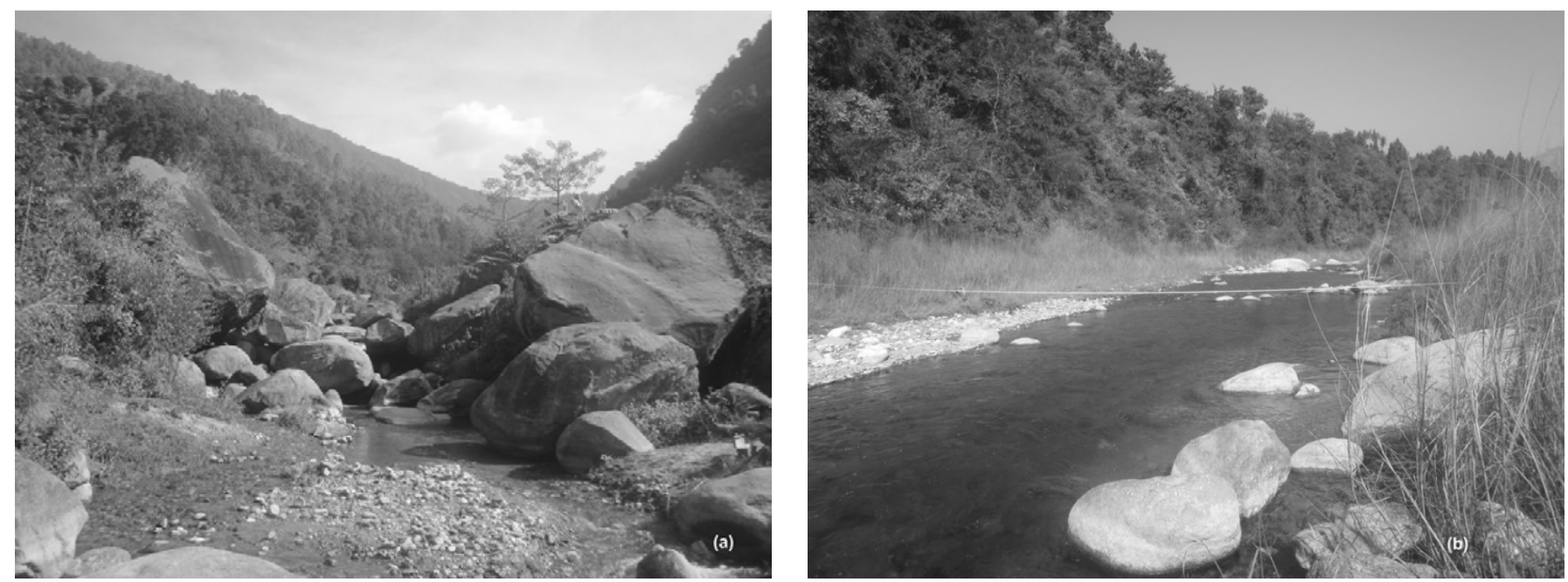

Fig. 7: Transect locations along the Malekhu Khola at a) Jamaran and b) Mawatar.

Table 4: Hydraulic parameters of the Malekhu Khola.

\begin{tabular}{|c|c|c|c|c|c|c|c|c|c|c|}
\hline Transect & $\mathbf{1}$ & $\mathbf{2}$ & $\mathbf{3}$ & $\mathbf{4}$ & $\mathbf{5}$ & $\mathbf{6}$ & $\mathbf{7}$ & $\mathbf{8}$ & $\mathbf{9}$ & $\mathbf{1 0}$ \\
\hline $\mathrm{A}_{\mathrm{bkf}}\left(\mathrm{m}^{2}\right)$ & 10.5 & 4.43 & 15.32 & 20.04 & 11.43 & 32.67 & 10.1 & 27.81 & 36.33 & 23.29 \\
\hline $\mathrm{W}_{\mathrm{bkf}}(\mathrm{m})$ & 11 & 10 & 20 & 30 & 17.5 & 30 & 18.3 & 22.3 & 32 & 23 \\
\hline $\mathrm{D}_{\mathrm{bkf}}(\mathrm{m})$ & 0.94 & 0.588 & 0.736 & 0.73 & 0.64 & 1.2 & 0.61 & 1.17 & 0.865 & 1.12 \\
\hline $\mathrm{W}_{\mathrm{bkf}} / \mathrm{D}_{\mathrm{bkf}}$ & 11.70 & 17.01 & 27.17 & 41.10 & 27.34 & 25 & 30 & 19.06 & 36.99 & 20.54 \\
\hline $\mathrm{W}_{\mathrm{fpa}}(\mathrm{m})$ & 22 & 17 & 51.5 & 123 & 54.5 & 58 & 38 & 129 & 66 & 72 \\
\hline $\mathrm{ER}$ & 2 & 1.7 & 2.57 & 4.1 & 3.11 & 1.93 & 2.08 & 4.96 & 2.06 & 3.13 \\
\hline $\mathrm{WP}(\mathrm{m})$ & 12.88 & 11.18 & 21.47 & 31.46 & 18.78 & 32.4 & 19.52 & 24.64 & 33.73 & 25.32 \\
\hline $\mathrm{R}(\mathrm{m})$ & 0.815 & 0.396 & 0.714 & 0.637 & 0.609 & 1.01 & 0.517 & 1.13 & 1.07 & 0.92 \\
\hline $\mathrm{S}(\mathrm{m} / \mathrm{m})$ & 0.033 & 0.046 & 0.03 & 0.035 & 0.04 & 0.054 & 0.029 & 0.039 & 0.055 & 0.048 \\
\hline $\mathrm{n}-\mathrm{value}$ & 0.100 & 0.085 & 0.096 & 0.122 & 0.142 & 0.122 & 0.113 & 0.086 & 0.092 & 0.109 \\
\hline $\mathrm{Q}_{\mathrm{bkf}}\left(\mathrm{m}^{3} / \mathrm{s}\right)$ & 16.59 & 6.02 & 4.70 & 22.85 & 11.54 & 62.73 & 9.76 & 69.24 & 97.00 & 44.25 \\
\hline $\mathrm{V}_{\mathrm{bkf}}(\mathrm{m} / \mathrm{s})$ & 1.58 & 1.36 & 0.307 & 1.14 & 1.01 & 1.92 & 0.966 & 2.49 & 2.67 & 1.9 \\
\hline
\end{tabular}

The values of the calculated hydraulic parameters (Table 4) are not homogenous for the MKW and their values fluctuate randomly for each transect. Bankfull area is maximum at Transect 9 and minimum at Transect 2. Width-Depth ratio is maximum at Transect 4 and minimum at Transect 1 . Flood prone width is maximum at Transect 8 and minimum at Transect 2. Entrenchment ratio is maximum at Transect 8 and minimum at Transect 2. Discharge is maximum at Transect 9 and minimum at Transect 3. Most of the maximum values are in downstream sections while most of the minimum values are in upstream sections. The geology and the land use might also be responsible for such fluctuation.

\section{HYDRAULIC GEOMETRY}

Different hydraulic parameters such as bankfull discharge $\left(\mathrm{Q}_{\mathrm{bkf}}\right)$, bankfull width $\left(\mathrm{W}_{\mathrm{bkf}}\right)$ and bankfull depth $\left(\mathrm{D}_{\mathrm{bkf}}\right)$ at each transect were plotted against the bankfull area $\left(\mathrm{A}_{\mathrm{bkf}}\right)$ and the subwatershed area (WA) contributing upto that transect. 

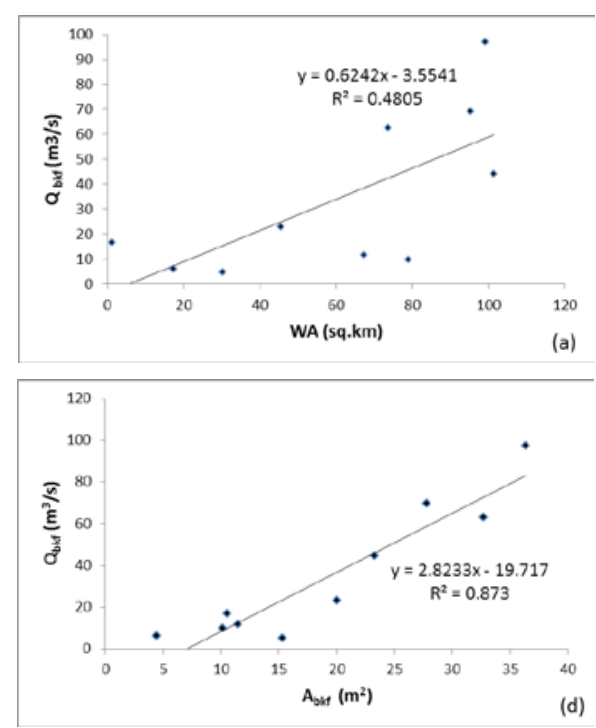

Fig. 8: Plots of various hydraulic parameter (f) $D_{\text {bkf }}$ vs $A_{b k f}$.

On the basis of the plots (Fig. 8), relations of $\mathrm{Q}_{\mathrm{bkf}}$ with WA and $\mathrm{W}_{\mathrm{bkf}}$ with WA show low degree of positive correlation. Correlation of $\mathrm{D}_{\mathrm{bkf}}$ with WA is positive. Similarly, relations of $\mathrm{Q}_{\mathrm{bkf}}$ with $\mathrm{A}_{\mathrm{bkf}}$ and $\mathrm{W}_{\mathrm{bkf}}$ with $\mathrm{A}_{\mathrm{bkf}}$ show significant positive correlation. The plot of $\mathrm{D}_{\mathrm{bkf}}$ with $\mathrm{A}_{\mathrm{bkf}}$ shows high degree of positive correlation.

\section{LEVEL II CLASSIFICATION OF THE MALEKHU KHOLA}

Five different parameters including $\mathrm{ER}, \mathrm{W}_{\mathrm{bkf}} / \mathrm{D}_{\mathrm{bkf}}, \mathrm{K}, \mathrm{S}$ and $\mathrm{D}_{50}$ were considered for the Level II Classification (Rosgen, 1993) of the Malekhu Khola. Stream type was decided at each transect (Table 6) on the basis of the calculated values as well as the adjustment made according to field experience.

Table 6: Level II classification of the Malekhu Khola.

\begin{tabular}{|c|c|l|c|}
\hline Taransect & Stream order & $\begin{array}{c}\text { Geological } \\
\text { Formation }\end{array}$ & $\begin{array}{c}\text { Stream } \\
\text { type }\end{array}$ \\
\hline 1 & 4 & Markhu Formation & $\mathrm{A} 4$ \\
\hline 2 & 4 & Markhu Formation & $\mathrm{A} 4$ \\
\hline 3 & 5 & Tistung Formation & $\mathrm{B} 4$ \\
\hline 4 & 6 & Tistung Formation & $\mathrm{C} 4$ \\
\hline 5 & 6 & Granite Intrusion & $\mathrm{B} 4$ \\
\hline 6 & 6 & Kulekhani Formation & $\mathrm{B} 4$ \\
\hline 7 & 6 & Kulekhani Formation & $\mathrm{C} 4$ \\
\hline 8 & 6 & Kalitar Formation & $\mathrm{C} 4$ \\
\hline 9 & 6 & Robang Formation & $\mathrm{C} 4$ \\
\hline 10 & 6 & Malekhu Limestone & $\mathrm{C} 4$ \\
\hline
\end{tabular}

The river reaches have been classified as A4-, B4- and C4type streams. A4- and B4-type streams are moderate-gradient gravelly and low sinuosity rivers whereas C4-type streams are low-gradient gravelly meandering river. The Malekhu Khola gradually changes from A4- to B4-type streams up to $12 \mathrm{~km}$ downstream, and then to C4-type stream further downstream, but B4-type streams reappear within the distance of $15 \mathrm{~km}$ to $19 \mathrm{~km}$ from the origin.

\section{STREAM COMPETENCY AND AGGRADING/ DEGRADING POTENTIAL}

Boundary shear stress $(\tau)$ and critical shear stress $\left(\tau_{c}\right)$ at bankfull stage for $d_{50}$ were obtained using following expressions respectively (Shields 1936):

$$
\begin{aligned}
& \tau=\gamma \operatorname{RS} \\
& \tau_{\mathrm{c}}=\theta_{\mathrm{c} .} \mathrm{g}\left(\rho_{\mathrm{c}}-\rho\right) \cdot \mathrm{d}_{50}
\end{aligned}
$$

where, $\gamma=$ unit weight of water $\left(9810 \mathrm{~N} / \mathrm{m}^{2}\right), \mathrm{R}=$ hydraulic radius $(\mathrm{m}), \mathrm{S}=$ slope of stream $(\mathrm{m} /), \theta_{\mathrm{c}}=$ Shields parameter for critical dimensionless shear stress which was taken as 0.045 from the Shields Curve for coarse-bedded stream, $\mathrm{g}=$ gravitational constant $\left(9.81 \mathrm{~m} / \mathrm{s}^{2}\right), \mathrm{d}_{50}=$ median diameter of particle $(\mathrm{m}), \rho_{\mathrm{c}}=$ density of sediment $(2,650 \mathrm{~kg} /$ $\left.\mathrm{m}^{3}\right), \rho=$ density of water $\left(1,000 \mathrm{~kg} / \mathrm{m}^{3}\right)$. 
Table 5: Stream competency parameters of the Malekhu Khola.

\begin{tabular}{|c|c|c|c|c|c|c|c|c|c|c|}
\hline Transect & $\mathbf{1}$ & $\mathbf{2}$ & $\mathbf{3}$ & $\mathbf{4}$ & $\mathbf{5}$ & $\mathbf{6}$ & $\mathbf{7}$ & $\mathbf{8}$ & $\mathbf{9}$ & $\mathbf{1 0}$ \\
\hline $\mathrm{d}_{50}(\mathrm{~m})$ & 0.064 & 0.064 & 0.016 & 0.032 & 0.032 & 0.032 & 0.032 & 0.032 & 0.032 & 0.032 \\
\hline $\mathrm{d}_{90}(\mathrm{~m})$ & 0.256 & 0.128 & 0.128 & 0.064 & 0.064 & 0.128 & 0.256 & 0.128 & 0.128 & 0.128 \\
\hline $\begin{array}{c}\tau \\
\left(\mathrm{KN} / \mathrm{m}^{2}\right)\end{array}$ & 0.264 & 0.179 & 0.210 & 0.219 & 0.239 & 0.534 & 0.146 & 0.432 & 0.577 & 0.433 \\
\hline $\begin{array}{c}\tau \mathrm{c} \\
\left(\mathrm{KN} / \mathrm{m}^{2}\right)\end{array}$ & 0.023 & 0.023 & 0.023 & 0.023 & 0.023 & 0.023 & 0.023 & 0.011 & 0.046 & 0.046 \\
\hline$\tau_{90}^{*}$ & 0.073 & 0.128 & 0.105 & 0.242 & 0.242 & 0.307 & 0.084 & 0.216 & 0.225 & 0.255 \\
\hline$\tau_{\mathrm{c} 90}^{*}$ & 0.249 & 0.456 & 0.136 & 0.456 & 0.456 & 0.249 & 0.136 & 0.249 & 0.249 & 0.249 \\
\hline $\mathrm{D}_{\mathrm{t}}(\mathrm{m})$ & 3.19 & 2.1 & 0.957 & 1.38 & 1.2 & 0.974 & 1.98 & 1.35 & 0.956 & 1.1 \\
\hline $\mathrm{S}_{\mathrm{t}}(\mathrm{m} / \mathrm{m})$ & 0.112 & 0.164 & 0.039 & 0.066 & 0.075 & 0.044 & 0.094 & 0.045 & 0.061 & 0.047 \\
\hline $\begin{array}{c}\Omega \\
(\mathrm{KNm} / \mathrm{s} / \mathrm{m} 2)\end{array}$ & 0.420 & 0.601 & 0.605 & 0.227 & 0.256 & 0.983 & 0.134 & 1.05 & 1.53 & 0.823 \\
\hline
\end{tabular}

At all transects, $\tau$ is found to be greater than $\tau_{c}$ (Table 5), so the stream is competent enough to carry the bed material upto size $\mathrm{d}_{50}$.

Dimensionless shear stress $\left(\tau_{i}^{*}\right)$ to explain the hydraulic condition required to entrain particles was calculated using following expression (Shields 1936):

$$
\tau_{\mathrm{i}}^{*}=\mathrm{DS} /\left(\mathrm{S}_{\mathrm{s}}-1\right) \mathrm{d}_{\mathrm{i}}
$$

where, $\mathrm{D}=$ average bankfull depth $(\mathrm{m}), \mathrm{S}=$ slope of stream $(\mathrm{m} / \mathrm{m}), \mathrm{S}_{\mathrm{s}}=$ specific gravity of sediment $(2.65), \mathrm{d}_{\mathrm{i}}=$ particle diameter coarser than $\mathrm{i}^{\text {th }} \%$ of the riverbed material.

Similarly, threshold dimensionless shear stress $\left(\tau_{\mathrm{ci}}{ }^{*}\right)$ required to entrain $d_{i}$ of the riverbed material was calculated using following expression (Andrews 1983):

$$
\tau_{\mathrm{ci}}^{*}=0.0834\left(\mathrm{~d}_{\mathrm{i}} / \mathrm{d}_{\mathrm{s} 50}\right)^{-0.872}
$$

where, $d_{i}=$ particle diameter coarser than $i^{\text {tho }} \%$ of the riverbed material, $\mathrm{d}_{\mathrm{s} 50}=$ median grain diameter of subsurface bed. In this study, $d_{i}$ of equations (5) and (6) were replaced by $\mathrm{d}_{90}$ to calculate the threshold dimensionless shear stress for the bed material of coarse percentile. In gravelly stream, the $\tau_{\mathrm{ci}}{ }^{*}$ value may range from 0.02 to 0.25 , and for the ratio $d_{i} / d_{s 50}$ greater than $4.2, \tau_{\mathrm{ci}}{ }^{*}$ becomes 0.02 but it may be as low as 0.01 for eroding stream (Andrews 1983).

The threshold bankfull depth, $\mathrm{D}_{\mathrm{t}}$ and threshold slope, $\mathrm{S}_{\mathrm{t}}$ required to trigger the movement of $\mathrm{d}_{\mathrm{i}}$ are expressed as:

$$
\begin{aligned}
& \mathrm{D}_{\mathrm{t}}=\left(1.65 \tau_{\mathrm{ci}} * \mathrm{~d}_{\mathrm{i}}\right) / \mathrm{S} \\
& \mathrm{S}_{\mathrm{t}}=\left(1.65 \tau_{\mathrm{ci}} * \mathrm{~d}_{\mathrm{i}}\right) / \mathrm{D}
\end{aligned}
$$

where, D is existing bankfull depth and $\mathrm{S}$ is existing slope.

It was observed that for Transect 6 and 10, D and S are greater than $S_{t}$ and $D_{t}$ while for the remaining ones, $D$ and $S$ are smaller than $S_{t}$ and $D_{t}$. This indicates that the Malekhu Khola is degrading in its upstream portions, and has enough competency to move even larger particles at Transect 6 and 10 , while it is aggrading and brings larger particles only during high flow period at the remaining transects.

Stream power $(\Omega)$ is a measure of the energy transfer. It is computed by following formula developed by Brookes (1990):

$$
\Omega=\tau \mathrm{V}
$$

Where, $\tau=$ boundary shear stress $\left(\mathrm{KN} / \mathrm{m}^{2}\right), \mathrm{V}=$ bankfull velocity $(\mathrm{m} / \mathrm{s})$

The stream power is maximum at Transect 9 and minimum at Transect 7 along the Malekhu Khola. Since, there is great difference between the $\tau$-value and $\mathrm{V}, \Omega$ is the function of both $\tau$ and $\mathrm{V}$.

\section{TEMPORAL CHANGE IN THE MALEKHU KHOLA CHANNEL}

The migration of river channels across their floodplains and the occasional erosion of terrace bank is a natural process (Leopold et al. 1964; Yang 1971, Dunne and Leopold 1978, Leopold 1994 and Thorne 1992 and 2002). But, this natural process is also affected by the disturbances created by the human activities such as channel sediments quarry, floodplain exploitation for cultivation etc. The Malekhu Khola also shows the channel migration characteristics or avulsion Fig. 6) even within the duration of 12 years. The change of channel path in downstream sections at Mawatar and Malekhu Bridge area might have been influenced by the extensive quarry of the channel sediments and exploitation of floodplain for cultivation. The upstream sections are relatively undisturbed and the change in channel path at Chhapdada, Simthali and Madhan are mainly due to the work done by the Malekhu Khola itself with some human disturbances at some places for cultivation. 


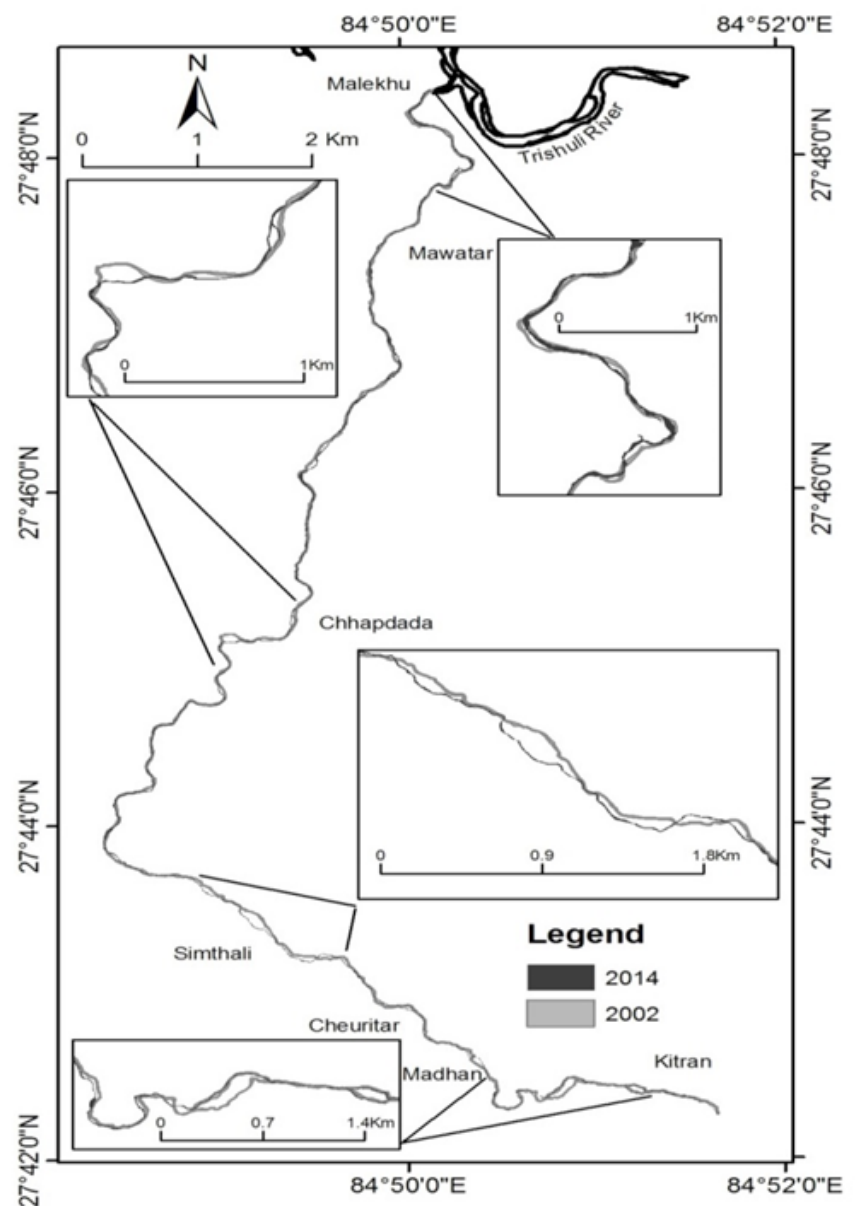

Fig. 10: Temporal change in Malekhu Khola channel from 2002 to 2014.

The river portion at the Simthali area shows much change in the channel pattern in comparison to other portions of the Malekhu Khola. Although the channels intersect each other frequently throughout the Malekhu Khola, the channel of 2014 seems to be migrating towards the right bank significantly in the highlighted sections. This might be due to the exploitation of the right bank by the dense settlement and quarry industries present at the right bank of the Malekhu Khola.

\section{CONCLUSIONS}

The Malekhu Khola is a sinuous river which is $24.83 \mathrm{~km}$ long sixth-order stream and has the watershed area of 101.28 $\mathrm{km}^{2}$. The fluctuating values of the hydraulic parameters at the ten transects indicate heterogeneity for the MKW. The geology and the land use are responsible for such fluctuation. Hydraulic geometry of the Malekhu Khola is better explained by the relations of bankfull area versus hydraulic parameters than the relations of subwatershed area versus the hydraulic parameters. The river reaches have been classified as A4-, B4- and C4type streams. The Malekhu Khola gradually changes from A4- to B4-type streams, and then to C4-type stream further downstream, but B4-type streams reappear within the distance of $15 \mathrm{~km}$ to $19 \mathrm{~km}$ from the origin. The Malekhu Khola shows the eroding tendency at $1.2 \mathrm{~km}, 16.6 \mathrm{~km}$ and $20 \mathrm{~km}$ from the origin, and is degrading and has enough competency to move even larger particles at Transect 6 and 10, while it is aggrading and brings larger particles only during high flow period at the remaining transects. The river shows the channel migration characteristics even within 12 years at Mawatar and Malekhu Bridge Area, Chhapdada, Simthali and Madhan area.

\section{REFERENCES}

Andrews, E. D., 1983, Entrainment of gravel from natural sorted riverbed material. Geol. Soc. Am. Bull., v. 94, pp. 1225-1231.

Brookes, A., 1990, Restoration and enhancement of engineered river channels: some European experiences. Regulated Rivers: Research and Management, v. 5(1), pp. 45-56.

Chow, V. T., 1959, Open channel hydraulic. Mc Graw-Hill, Inc. New York, $680 \mathrm{p}$.

Dunne, T. and Leopold, L. B., 1978, Water in environmental planning. W.H. Freeman and Company, New York, $818 \mathrm{p}$.

Leopold, L. B., 1994, A View of the River. Harvard University Press, Cambridge, Massachusetts. 298 p.

Leopold, L. B. and Wolman, M.G., 1957, River Channel Patterns: Braided, Meandering and Straight. U. S. Geological Survey, pp. 39-85.

Leopold, L. B., Wolman, M.G., and Miller, J. P., 1964, Fluvial processes in Geomorphology. W. H. Freeman, San Fransisco, $522 \mathrm{p}$.

Marutani, T., Brierly, G. J., Trustrum, N. A., and Page, M., 2001, Source-to-sink sedimentary cascades in Pacific Rim geo-system. Matsumoto sabo work office, Ministry of Land Infrastructure and Transport, Japan. pp. 36-43.

Nadgir, B. B., Gandotra, V. M., Nanda, M. M., Pawde, M. B., and Sharma, P.N., 1968-73. Nepal mission field reports. Unpubl. Rep., Geol. Surv. India, Calcutta \& Kathmandu.

Rosgen, D. L., 1994, A Classification of natural rivers. Catena, v. 22, pp. 169-199.

Schumm, S. A., 1963, A tentative classification system of alluvial rivers. Circular 477, USGS, Washington, D. C., pp. $1-10$

Selby, M. J., 1993, Earth's Changing Surface, An Introduction to Geomorphology. 239 p.

Shields, A. 1936, Application of similarity principles and turbulence research to bed-load movement. In: W.P. Ott and J.C. Uchelen (translators), Mitt. Preuss. Verschsanst., Berlin. Wasserbau Schiffbau. California Institute of Technology, Pasadena. CA, Report, 167, 43 p.

Stocklin, J., 1980, Geology of Nepal and its regional frame. Jour. Geol. Soc. London, v. 137, pp. 1-34.

Strahler, A. N., 1957, Quantitative analysis of watershed geometry. Trans-American Geophysical Union, v. 38, pp. 913-920. 
Strahler, A. N., 1964, Quantitative geomorphology of drainage basins and channel networks, In: VT Chow (ed.), Handbook of Applied Hydrology. McGraw-Hill Book Company, New York, Section, pp. 4-11.

Tamrakar, N. K. and Bajracharya, R., 2012, Basinal and planform characteristics of the Kodku and the Godavari Rivers, Kathmandu, Central Nepal. Bull. of the Dept. Geol., Tribhuvan University, Kathmandu, Nepal, v. 15, pp. 15-22.

Tamrakar, N. K. and Shrestha, M. B., 2008, Relationship between fluvial clastic sediment and source rock abundance in Rapti River Basin of Central Nepal Himalaya. Boletin de Geologia, v. 30(1), pp. 63-75.
Tamrakar, N. K. and Shrestha, P., 2012, Morphology and classification of the main stem Bagmati River, central Nepal. Bull. Dept. Geol., Tribhuvan University, Kathmandu, Nepal, v. 15, pp. 23-34.

Thorne, C. R., 1992, Inaugural Lecture, River meanders: Nature's answer to the straight line. Univ. Nottingham, Dept. Physical Geography, Nottingham, England.

UNDP, 1981. Geology of Kathmandu area and Central Mahabharat Range, Nepal Himalaya. New York, 64 p.

Yang, C. T., 1971, On river meanders. Jour. Hydrology, v. 13, pp. 231-253. 